\title{
PENGEMBANGAN POTENSI EKSTRAK KULIT BUAH RAMBUTAN SEBAGAI BAHAN OBAT HERBAL ANTIHIPERKOLESTEROL
}

\author{
Muhtadi*, Haryoto, Tanti Azizah Sujono, Peni Indaryudha, dan Andi Suhendi \\ Fakultas Farmasi, Universitas Muhammadiyah Surakarta \\ Correspondence to: Muhtadi \\ Email:muhtadi@ums.ac.id
}

\begin{abstract}
The rind of rambutan fruit (Nephelium lappaceum L.) has been reported to have a very strong antioxidant activity with IC50 value of $7.74 \mu \mathrm{g} / \mathrm{mL}$. The fruit contains flavonoids and phenolic. This compounds are potentially as hypolipidemic effect. This study aims to determine the hypolipidemic effect of $96 \%$ of ethanolic extract of rind of rambutan fruit in wistar strain male rats. This research method is the pre- and post-control group design. 25 rats were divided into 5 groups. Group I (negative control) were treated by a solution of 0.5\% CMC-Na, group II (positive control) were treatedby cholestyramine $0.8 \mathrm{~kg} / \mathrm{kg}$, whereas group III, IV and V treated by $96 \%$ of ethanolic extract of rind of rambutan with a dose of 125,250 , and $500 \mathrm{mg} / \mathrm{kg}$ respectively. hiperkolesterlemia induction is done by giving a high cholesterol diet and feed for 4 weeks. High-cholesterol diet consists of cooking oil, quail egg yolk, water, PTU and feed high cholesterol consisting of margarine and standard feed. Treatment of mice was conducted for 2 weeks. The results showed that the $96 \%$ of ethanolic extract of rind of rambutan fruit with a dose of 125, 250, and $500 \mathrm{mg} / \mathrm{kgbw}$ have antihyperkolesterol activity $21.39 \pm 6.61 \%, 31.15 \pm 18.15 \%$, and $60.75 \pm 8,26 \%$.
\end{abstract}

Keywords: Antihypercholestrol, Nephelium Lappaceum L., High-cholesterol diet

\section{PENDAHULUAN}

Penyakit hiperkolesterol merupakan penyakit degeneratif yang banyak dijumpai kasusnya di Indonesia, dan menunjukkan kecenderungan peningkatan jumlah prevalensi setiap tahunnya. Penyakit kolesterol adalah penyakit yang disebabkan oleh endapan lemak yang terdapat dalam pembuluh darah dapat menyebabkan penyempitan pembuluh darah karena dinding pembuluh darah menjadi lebih tebal (Poedjiadi, 2006). Kolesterol secara normal diproduksi oleh tubuh dalam jumlah yang tepat. Namun perubahan pola makan yang cenderung berupa makanan dari hewani dan berlemak tinggi, menyebabkan kolesterol berada dalam jumlah yang banyak didalam darah. Peningkatan kadar kolesterol dalam darah merupakan faktor utama aterosklerosis yang berkaitan dengan penyakit jantung koronari yang dapat mengakibatkan banyak kasus kematian (Ratnawati dan Wahyu, 2011).
Saat ini banyak sekali beredar di pasaran, obat-obatan untuk penurun kolesterol baik obat alami maupun obat sintetis. Namun karena penggunaan obatmodernatau sintetis memilikiefek samping seperti retensi air dengan hiponatremi, gangguan gastrointestinal (Krentz and Bailey, 2005), maka kecenderungan masyarakat saat ini lebih memilih obat alami karena obat alami diyakini lebih aman, murah dan mudah ditemukan bahan bakunya di sekitar masyarakat, dibanding obat sintetis (Lin, 2010). Fenomena ini menjadi perhatian khusus di kalangan para peneliti bahan alam.

Pada tahun 1980 WHO merekomendasikan agar dilakukan penelitian terhadap tanaman yang memiliki efek farmakologi karena pemakaian obat modern yang kurang aman (Kumar et al, 2005). Salah satunya adalah hasil penelitian in vitro yang menerangkan bahwa ekstrak etanol dari kulit buah durian (Roongpisuthipong et al., 1991) dan kulit buah rambutan (Manaharan et al., 2012) memiliki 
aktivitas sebagai antihiperglikemik. Kulit buah rambutan mengandung flavonoid, tanin dan saponin (Dalimartha, 2003). Ekstrak etanol kulit buah rambutan mengandung epigallocatechin-3gallate (Palanisamy et al., 2011) yang memiliki aktivitas sebagai antihiperglikemia (WaltnerLaw et al., 2002) serta antioksidan kuat (Tabata et al., 2008). Ekstrak etanol kulit buah rambutan diketahui memiliki kemampuan yang lebih besar sebagai antioksidan untuk menangkap radikal bebas DPPH dibandingkan dengan vitamin $\mathrm{E}$ (Tamimiy, 2006).

Penderita penyakit degeneratif umumnya memiliki tingkat stres oksidatif yang tinggi sebagai efek dari ketidakseimbangan antara antioksidan protektif dan peningkatan produksi radikal bebas yang dapat memicu munculnya komplikasi (Setiawan dan Suhartono, 2005). Sehingga untuk mencegah terjadinya komplikasi pada kondisi diabetes perlu diberikan antioksidan (Sujono dan Sutrisna, 2010). Haruenkit et al. (2010) menerangkan bahwa kandungan polifenol, flavonoid, flavanol, asam askorbat dan tanin berperan sebagai antioksidan. Polifenol dan antioksidan golongan fenol seperti katekin dapat menangkap radikal bebas dan mengurangi stres oksidatif (Widowati, 2008).

Berdasarkan hal-hal tersebut di atas maka dalam tulisan ini akan dijelaskan apakah ekstrak etanol kulit buah rambutan (Nephelium lappaceum L.) memiliki aktivitas farmakologi yang kuat sebagai antihiperkoleseterol yang diujikan secara in vivo pada tikus putih jantan galur wistar.

\section{METODE PENELITIAN}

Penelitian ini termasuk dalam jenis penelitian eksperimental dengan menggunakan metode pre and post test control group design. Variabel bebas pada penelitian ini meliputi seri dosis ekstrak etanol kulit buah rambutan. Variabel tergantung pada penelitian ini adalah kadar kolesterol dalam darah tikus. Variabel kendali dalam penelitian ini adalah hewan uji berupa tikus putih galur wistar (jenis kelamin, umur, berat badan).

Bahan penelitian ini adalah ekstrak etanol kulit buah rambutan (Nephelium lappaceum L.), tikus putih jantan galur wistar dengan umur 2-3 bulan dan berat 150-300 gram, CMC-Na 0,5\%, etanol $96 \%$, aquadestilata steril for injection. Reagen Cholesterol FS dari DiaSys Diagnostic
Systems GmbH, etanol 96\%, aseton, margarin, minyak goreng, kuning telur puyuh, PTU (propiltiourasil), kolestiramin.

Alat yang digunakan adalah Spektrofotometer UV-Vis (Stardust), kuvet (Plastibrand), timbangan hewan, neraca analitik, corong Buchner, rotary evaporator, waterbath, mikropipet, minispin (ependorf), vortex, alat suntik, jarum oral, holder dan alat-alat gelas.

Kulit buah rambutan diambil dari pedagang buah di Kecamatan Colomadu Kabupaten Karanganyar, kulit buah dibersihkan dengan sikat, dirajang tipis, dikeringkan kemudian diserbuk dengan blender. Serbuk yang telah jadi digunakan untuk ekstraksi.

Ekstraksi dilakukan dengan merendam masing-masing 2000 gram kulit buah rambutan dengan pelarut campuran etanol $96 \%$ dan aseton (8:2 L) yang didiamkan selama tiga hari sambil sesekali diaduk, pengadukan dilakukan minimal 3 kali sehari. Filtrat kemudian diambil dan disaring dengan corong Buchner. Ampas kulit buah diremaserasi kembali. Filtrat dikumpulkan dan penyari diuapkan kembali menggunakan rotary evaporator sehingga diperoleh ekstrak kental etanol kulit buah durian dan kulit buah rambutan. Ekstrak kental tersebut dikeringkan menggunakan penangas air. Rendemen ditimbang bobot keringnya dan dicatat sebagai bobot ekstrak etanol.

Pemberian pakan dan diet tinggi lemak dilakukan selama 28 hari. Diet tinggi lemak terdiri dari $50 \mathrm{~mL}$ minyak goreng, $10 \mathrm{~g}$ kuning telur puyuh, PTU 0,1\% dan air sampai 100,0 mL. Cara membuatnya yaitu dengan mencampur seluruh bagian minyak goreng dan kuning telur puyuh kemudian ditambah air hingga $100 \mathrm{~mL}$. PTU $0,1 \%$ dicampur dalam air minum (botol minum). Diberikan dengan dosis $2 \mathrm{~mL} / 200 \mathrm{~g}$ BB dan selalu dibuat baru. Selain itu diberi pakan tinggi lemak, terdiri dari $150 \mathrm{~g}$ pakan standar (pellet), 20 g kuning telur puyuh, dan $50 \mathrm{~g}$ margarin. Cara membuatnya yaitu margarin dipanaskan hingga leleh kemudian semua bahan dicampur dan diaduk sampai rata. Pakan tinggi lemak diberikan sebanyak $30 \mathrm{~g} /$ hari.

Hewan uji yang digunakan yaitu tikus putih sebanyak 25 ekor dibagi menjadi 5 kelompok. Setiap kelompok terdiri dari 5 ekor tikus yang dibagi secara random. Semua hewan uji diadaptasikan terlebih dahulu dengan diberi 
pakan standar dan aquadest ad libitum selama 7 hari. Sebelum pemberian diet dan pakan tinggi kolesterol terlebih dahulu dilakukan pengukuran kadar awal kolesterol total. Pengukuran kadar kolesterol total diukur sebelum diberi diet tinggi lemak (kadar awal), 4 minggu setelah diet tinggi lemak dan 2 minggu setelah pemberian ekstrak. Sampel darah tikus diambil sebanyak $1,5 \mathrm{~mL}$ dari vena ekor.

Diet dan pakan tinggi lemak diberikan selama 4 minggu. Pakan tinggi lemak sebanyak 30 $\mathrm{g} /$ hari/ 5 ekor dan diet tinggi lemak dengan dosis $2 \mathrm{~mL} / 200 \mathrm{gBB}$. Sedangkan perlakuan pemberian ekstrak dilakukan selama 2 minggu (setelah hiperkolesterolemia dengan kadar kolesterol total $>150 \mathrm{mg} / \mathrm{dL}$ ) pada semua kelompok:

Kelompok 1: CMC-NA 0,5\% (kontrol negatif)

Kelompok 2: Kolestiramin $0.8 \mathrm{~g} / \mathrm{kgBB}$ (kontrol positif).

Kelompok 3 : Ekstrak etanol kulit buah rambutan dosis $125 \mathrm{mg} / \mathrm{kgBB} /$ hari

Kelompok 4 : Ekstrak etanol kulit buah rambutan dosis $250 \mathrm{mg} / \mathrm{kgBB} /$ hari

Kelompok 5 : Ekstrak etanol kulit buah rambutan dosis $500 \mathrm{mg} / \mathrm{kgBB} /$ hari

\section{HASIL DAN PEMBAHASAN}

Ekstraksi dengan metode maserasi ini menggunakan pelarut campuran etanol $96 \%$ dan aseton $(4: 1 \mathrm{~L})$ untuk $2,0 \mathrm{~kg}$ serbuk kulit buah rambutan. Penggunaan pelarut campuran etanol dan aseton menghasilkan ekstrak yang baik karena campuran pelarut tersebut tidak beracun, netral, panas yang diperlukan untuk pemekatan lebih rendah dan etanol dapat bercampur dengan aseton pada segala perbandingan (Sanjaya, 2012). Bobot ekstrak kental kulit buah rambutan adalah 543,2 gram dengan rendemen sebesar $27,16 \%$.

Uji efek penurunan kolesterol dilakukan untuk mengetahui pengaruh ekstrak kulit buah rambutan dalam menurunkan kadar kolesterol dalam darah dengan menggunakan tiga peringkat dosis yang berbeda untuk masingmasing ekstrak. Kontrol positif diberi perlakuan berupa pemberian kolesteramin $0,8 \mathrm{~g} / \mathrm{KgBB} /$ hari. Menurut Wulandari (2009) pemberian kolesteramin $800 \mathrm{mg} / \mathrm{Kg}$ BB dapat menurunkan kadar kolesterol sebesar $52.97 \pm 1.12 \%$ jika diberikan selama 30 hari. Sementara pada penelitian ini kolesteramin diberikan selama 14 hari ( 2 minggu) dan dapat menurunkan kolesterol darah sebesar $34.20 \pm 10.42 \%$. Kontrol negatif yang digunakan adalah CMC-Na $0.5 \%$ karena CMC-Na tidak mempengaruhi kadar kolesterol dalam darah.

Berdasarkan data hasil pengujian antihiperkolesterol pada Tabel 1, ekstrak kulit buah rambutan pada dosis $500 \mathrm{mg} / \mathrm{Kg} \mathrm{BB}$ memiliki aktivitas menurunkan kadar kolesterol dalam darah tikus paling besar, yaitu $60,75 \%$ lebih kuat dibandingkan dengan kontrol positif (koletramin, dosis $800 \mathrm{mg} / \mathrm{KgBB}$ ). Hal ini menunjukkan bahwa ekstrak etanol kulit buah rambutan sangat poten sebagai bahan obat herbal antihiperkolesterol.

Kulit buah rambutan dilaporkan mengandung senyawa-seanya flavonoid, tanin dan saponin (Dalimartha, 2003). Ekstrak etanol kulit buah rambutan mengandung epigallocatechin3-gallate (Palanisamy et al., 2011) yang diduga memiliki aktivitas sebagai antihiperglikemia (Waltner-Law et al., 2002) serta antioksidan kuat (Tabata et al., 2008).

Tabel 1. Penurunan Kadar Kolesterol setelah diberi Ekstrak (kadar kolesterol mg/dl)

\begin{tabular}{ccccc}
\hline Perlakuan & Baseline & Induksi 4 minggu & Setelah Pemberian Ekstrak & Penurunan Kadar(\%) \\
\hline $\begin{array}{c}\text { Kontrol Positif } \\
\text { (kolesteramin) }\end{array}$ & $58,6 \pm 4,16$ & $116,8 \pm 10,23$ & $77,2 \pm 16,02$ & $34,20 \pm 10,48$ \\
Kontrol Negatif (CMC-Na) & $61 \pm 11,87$ & $145,8 \pm 23,40$ & $126,6 \pm 32,17$ & $13,44 \pm 15,45$ \\
Rambutan 500 mg & $78,8 \pm 18,75$ & $203,2 \pm 43,41$ & $80,2 \pm 24,71$ \\
Rambutan 250 mg & $62,2 \pm 5,36$ & $133,6 \pm 30,01$ & $88,2 \pm 15,64$ & $31,15 \pm 18,15$ \\
Rambutan 125 mg & $61,2 \pm 6,34$ & $180,2 \pm 12,68$ & $141 \pm 2,92$ & $21,39 \pm 6,61$ \\
\hline
\end{tabular}

Berdasarkan kajian literatur senyawasenyawa fenolik tersebut yang diduga memiliki aktivitas sebagai penurun kadar kolesterol dalam ekstrak kulit buah rambutan, namun mekanisme aktivitas farmakologinya belum dapat diketahui secara pasti. 


\section{KESIMPULAN}

1. Ekstrak etanol kulit buah rambutan pada dosis 125 , 250, dan $500 \mathrm{mg} / \mathrm{KgBB}$ memiliki efek antihiperkolesterol dengan nilai persentase penurunan kolesterol sebesar $21,39 \pm 6,61 \%$, $31,15 \pm 18,15 \%$, dan $60,75 \pm 8,26 \%$.

2. Secara keseluruhan ekstrak etanol kulit buah rambutan sangat poten sebagai bahan obat herbal antihiperkolesterol.

\section{DAFTAR PUSTAKA}

Dalimartha, S., 2003, Atlas Tumbuhan Obat Indonesia, Jilid 2, Jakarta, Puspa Swara.

Depkes, 2005, Pharmaceutical Care Untuk Penyakit Diabetes Melitus, Jakarta, Departemen Kesehatan RI.

Haruenkeit, R., Poovarodom, S., Vearasilp, S., et al., 2010, Comparison of Bioactive Compounds, Antioxidant and Antiproliferative Activities of Mon Thong Durian During Ripening, Food Chemistry, 118, 540-547.

Kumar, E. K., Ramesh, A., and Kasiviswanath, R., 2005, Hypoglicemic and Antihyperglicemic Effect of Gmelina asiatica Linn. in Normal and in Alloxan Induced Diabetic Rats, India, Department of Pharmaceutical Sciences Ardha Pradesh.

Krentz, A. J., and Bailey, C. J., 2005, Oral Diabetic Agents Current Role in Type 2 Diabetes Melitus, Riview Article, 65 (3), 394, 398, 403.

Lee, Soo-Kyung, Hwang, Ji-Yeon, et al., 2007, Inhibitory Activity of Euonymus alatus against alpha-glucocidase In Vitro and In Vivo, Nutrition Research and Practice, 184188.

Leontowicz, H., Maria, L., Iwona, J., et al., 2011, Positive Effects of Durian Fruit At DifferentStages of Longan (Dimocarpus longan) Ripening On The Hearts and Livers of Rats Fed Diets High in Cholesterol, European Journal of Integrative Medicine, 3, 169-181.

Manaharan T., Teng L, L., Appleton D., Ming C, H., Masilamani T., Palanisamy U, D., 2011, Antioxidant and antiglycemic potential of Peltophorum pterocarpum plant parts, Food Chem, 129 (4), 1355-1362.

Manaharan, T., Palanisamy, U. D., and Ming, C. H., 2012, Tropical Plant Extracts as Potential Antihyperglycemic Agents, Article 17, 5915-5923.

Palanisamy, U. D., Ling, L. T., Manaharan T., Appleton,
D., 2011, Rapid Isolation of Geraniin From Nephelium lappaceum Rind Waste and it's Anti-Hyperglycemic activity, Food Chemistry 127, 21-27.

Sanjaya, A., 2012, Pembuatan Serbuk Pewarna Makanan Dari Ekstrak Daun Suji (Pleomele angsutifolia) Secara Ekstraksi Soxhlet dan Ekstraksi Maserasi (Online), (http:// lib.unnes.ac.id/12466, diakses tanggal 23 Desember 2013)

Sujono, T. A., dan Sutrisna, EM., 2010, Pengaruh Lama Praperlakuan Flavonoid Rutin terhadap Efek Hipoglikemik Tolbutamid pada Tikus Jantan yang Diinduksi Aloksan, Jurnal Penelitian Sains dan Teknologi, Volume 11 No 2, 94, 97.

Sunarsih, S. E., Djatmika, Utomo, R. S., 2007, Pengaruh pemberian infusa umbi gadung (Dioscorea hispida Dennst) terhadap penurunan kadar glukosa darah tikus putih jantan diabetes yang diinduksi aloksan, Majalah Farmasi Indonesia, 18(1), 32.

Tabata, H., Katsube, T., Tsuma, T., Ohta, Y.,, Imawaka, N., dan Utsumi, T., 2008, Isolation and evaluation of the radical-scavenging activity of the antioxidants in the leaves of an edible plant Mallotus japonicus, Food Chemistry, 109 (1), 64-71.

Tamimy, 2006, Aktivitas Antioksidan Ekstrak Etanol Kulit Buah Rambutan (Nephellium lappaceum L.) Terhadap Peredaman Radikal Bebas DPPH Secara Spektrofotometri, Yogyakarta, Sinar Tampak.

Waltner-Law M, E., Wang X, L., Law B, K., Hall R, K., Nawano, M., 2002, Epigallocatechin gallate, a constituent of Green tea represses hepatic glucose production, Journal, 277(38), 34933-34940.

Watkins D., Cooperstein S. J., and Lazarow A., 2008, Effect of alloxan on permeability of pancreatic islet tissue in vitro, Journal, American Physiological Society,207(2): $436-440$.

WHO, 1999, Definition, Diagnosis and Classification od Diabetes Melitus and it's Complications, Geneva, World Health Organization Department on Noncommunicable Disease Surveillance.

Widowati, W., 2008, Potensi Antioksidan sebagai Antidiabetes, Jurnal, JKM, Vol7(2): 2,3,5-7. 